\title{
Strategy of Values Education in the Indonesian Education System
}

\author{
Suyatno \\ Dr., Universitas Ahmad Dahlan Yogyakarta, Indonesia, suyatno@pgsd.uad.ac.id

\section{Jumintono} \\ Universitas Ahmad Dahlan Yogyakarta, Indonesia, masmintosragen@gmail.com
}

Dholina Inang Pambudi

Universitas Ahmad Dahlan Yogyakarta, Indonesia, dholina.pambudi@pgsd.uad.ac.id

\section{Asih Mardati}

Universitas Ahmad Dahlan Yogyakarta, Indonesia, asihmardati@gmail.com

\section{Wantini}

Universitas Ahmad Dahlan Yogyakarta, Indonesia,wantini@mpai.uad.ac.id

The primary question of this research was how educators implement values education at Junior High Schools in Bangka Belitung Province, Indonesia. This research is a qualitative research with phenomenology type. Data analyzing technique used in this research was in-depth interviews, observation, and document analysis. Data analysis was done through data display, data reduction, and conclusion. The result showed that values education at Junior High School in Bangka Belitung started with the preparation of school vision based on values, and then the achievement of vision through the preparation of values education strategy. Habituation of values and values role model became the most dominant strategies used by principals and teachers to cultivate values. The results also showed that the values derived from religious teachings, namely the values of iman-taqwa (faith-piety) and good akhlaq (morals) were the most important values serve as a foundation in developing values education in schools. The big role of iman-taqwa (faith-piety) and good akhlaq (morals) values constitutes the effort done by the school to contribute in achieving the purposes of national education and curriculum of 2013. The final purpose of K-13 implementation and the national education system achievement is the formation of Indonesian whose strong faith and good morals.

Keywords: values education, values education strategy, school vision, role model, faithpiety, good morals

Citation: Suyatno, Jumintono, Pambudi, D. I., Mardati, A., \& Wantini (2019). Strategy of Values Education in the Indonesian Education System. International Journal of Instruction, 12(1), 607-624. https://doi.org/10.29333/iji.2019.12139a 


\section{INTRODUCTION}

Values education, some call it as character education, moral education, and ethics education (Lovat \& Toomey, 2009), again become an interesting issue in Indonesia in recent years. In fact, this theme is also strategic education policy agenda in various countries in the world (Nesbitt et al., 2005; Holmes \& Crossley, 2004; Prencipe \& Helwig, 2002; Tatto et al., 2001). Therefore, Taplin (2002) stated that values education is becoming increasingly important at all levels of schooling.

Failure to implement values education is due to many factors. Hadi (2015) said that teachers in schools do not yet have enough skills to integrate values in classroom learning. According to Brady (2011), even though values education concerns about teachers role, one factor that is consistently ignored on values education polemic is the effects of personal values of the teachers themselves, and how the values are expressed in classroom teaching. Besides the teachers' role, Tutkun, et al. (2017) stated that the curriculum in schools is not in accordance with the values education. Muqowim (2014) explained that the failure of values education is much due to what happens in schools is education about values rather than values-based education.

Education about values means that the educational process undertaken puts more emphasis on values debates, not how to make those values come true within the lives of students. Sutrop, et al. (2013) explained that with values education, students not only recognize values but also habituate life with values. Effective values education requires appropriate strategy. Nurdin (2015) found out that the obstacles faced in the implementation of values education lie to the commitment and quality of the actors and their learning methods.From those research results, it can be outlined several factors that influence the failure of values education in a school such as: the lack of teachers' skill, the assumption that teachers' role is not vital, irrelevant curriculum, and values education that tends to focus on values argumentation rather than the strategy to grow the values on the students.

Values education or character education in Indonesia, in the recent development (after Laws Number 23 of 2003 on National Education system released) always becomes a priority program in the national education system. The curriculums proposed, including Competency-Based Curriculum (KBK in 2004), Education Unit Level Curriculum (KTSP in 2006) and 2013 Curriculum (K-13 in 2013) always put character education as the spirit on the curriculum implementation in the classroom. Even, in the K-13 which is implemented in present time emphasizes on the character education which then leads all subjects in the school to contribute directly on the formation of the students' character. The curriculum contribution on the students' character formation is put on the core competency 1 (learning outcome: religious character) and core competency 2 (learning outcome: social attitude). Therefore, the formation of a student's characters, both religious and social character becomes an indicator of the success of curriculum implementation in the school.

The development of character education in Indonesia keeps growing since the Presidential Decree Number 87 of 2017 released to strengthen the character education 
implementation in Indonesia. In this Presidential Decree, it is mentioned that the strengthening of character education (which then called as PPK) is an education movement which becomes the responsbility of education unit to strengthen the character of students through the harmonization of heart control, feel, mind control, and sport by involving the integrity of education, family, and society unit as the part of National Movement of Mental Revolution. PPK has three main purposes; they are building and attaching Pancasila soul and a good character education to the students for anticipating the fluctuational differences in the future; developing a national education platform which emphasizes on the character education as the main soul in performing the education for the students by involving public support through formal, non-formal, and informal education along with considering the diversity of Indonesian culture; revitalizing and strengthening both potency and competency of the educators, educational staffs, students, society, and family environment in implementing PPK.

Previous research on values education has been carried out by previous researchers, both in Indonesia and in the international community. Ulavere and Veisson (2015) emphasize the importance of teachers in value education. Savucu, et al., (2017) found that students who have good values can reduce the tendency of bullying in schools. Chong \& Cheah (2009) research results emphasize the importance of values that must be owned by the teacher in Singapore in order to successfully implement the value education curriculum. Besides, research on values education in Indonesia was carried out by Arifin, et al. (2017) and Sutiyono (2013). Arifin, et al. (2017) reveals about the importance of transforming school cultural values both in managing curriculum, learning, students, teachers, and school practitioners in implementing character education. Sutiyono's research (2013) emphasizes the importance of value education that is integrated in all school subjects and curriculum. Compared to previous studies, this research reveals the school strategy and the teacher in instilling character in the students in the western part of Indonesia which have different place, actor, and activity characteristics from the eastern and central parts of Indonesia.

According to the previous explanation related to the background of the study, the implementation of values education in Indonesia becomes an interesting topic to analyze. This research was conducted in six Junior High Schools (SMP) in Bangka Belitung Province in consideration that this topic is suitable to the platform of the government in Indonesia who want to build the country starting from rural areas. Bangka Belitung Province is a part of Sumatera Island which has separated land area from the main island. Geographically, this area is located in the western part of Indonesia which also belongs to the rural areas of Sumatera.

\section{LITERATURE REVIEW}

Many experts attempt to describe the concept of values and values education. Lickona (2004) illustrates that values are visible. Value consists of good nature as a form of appropriate moral behavior. Thus, value is a form of concrete behavior, or application of morals. Good character that underlying moral is referred as the value when it is manifested in the form of visible behavior. Yildirim \& Dilmac (2015) stated that value is closely related to human emotions, thoughts and behaviors. Senturk \& Aktas (2015) 
explain that human as social being accommodates their society by absorbing their values, attitudes, and beliefs. Cavus (2015) stated that value not only affecting culture but also influenced by culture, including the quality of being a good citizen. The symptoms of value can be seen from everyday behavior. Philosophers are more interested in differentiating values, for example, to differentiate behaviour values within the context of means values and end values (Kirschenbaum, 1995). Print (2000) explained that values play an important role in the educative and developmental processes of society, especially in democratic societies. Therefore, value education is very important to be lived in families, schools and society (Nguyen, 2016).

The process of education in schools should be directed to the formation of students' good value. The formation of good values can lead to student cohesion, open climate, honest communication, strengthening relationships, art of listening, trust, being positive to friends, emotional expressions and sentiments, and self-esteem growth (Sankar, 2004). Students' good values can reduce bullying trends on students (Savucu, et al., 2017). In fact, Bette's research (2011) found that value education can be a catalyst for national development.

In Indonesia, values education has been set in the national education system. There are eighteen values that teachers need to integrate in learning. The eighteen values are religious, honest, tolerance, disciplined, hardworking, creative, independent, democratic, curious, nasionalistic, patriotic, appreciative of achievements, friendly and communicative, peace loving, fond of reading, environmentally aware, socially concerned, and responsible (Kemendiknas, 2010). These values are cultivated by integrating values with the contents of the written curriculum, the unwritten curriculum (hidden curriculum), as well as the cocurriculum activities and extracurricular activities. It means that the value to be developed must be realized in the content of each subject through the process of learning in the classroom, the task outside the classroom, and also manifest in the school rules. As explained by Sutiyono (2013), the design of value education should not be in the form of certain subject, but the practice of those values absorb as content in every learning activities in school. Thus, each subject should containing value.

Krull (2000) suggested that values should be transferred through all learning and educational activities in the school. In addition, this research puts the importance of the formulation of school's vision based on value. In fact, vision has more important role because education strategy is applied in order to achieve the school vision. As the results of Raihani's research (2008), successful schools are preceded by the vision formulation as the guide of all policies, programs, and school activities.

Implanting the values to the students in the school can be achieved through many ways. Maragustam (2014) found out that there are six strategies in the values formation which requires sustainability processes such as values habituation, culturing values, moral knowing, feeling and loving the good, moral acting, dan exemplary values. Mislia \& Darman (2016) stated that the most commonly used strategies in the formation of character in students are; intervention, role model, habituation, facilitation, reinforcement, and involvement of others. 
Teachers also play a vital role in performing the values education. Moreover, Lovat \& Clement (2008) stated that there are only two duties of teachers; duties on values education and the "rest". Therefore, it is required for the teachers to study about the strategy used to teach the good values to students through either formal or non-formal education. The role of the teachers as role model for students is considered very important in values education (Ulavere \& Veisson, 2015). Teachers as guide in values education also have the task of creating suitable environment for students' development. In addition, the assurance of teachers toward the students also becomes an important factor of the success of values education in a school. According to Chong \& Cheah (2009), the main values that must be possessed by a teacher to support the success of a curriculum implementation at National Institute of Education (NIE), Singapore are: a belief that all students can learn, taking care and paying attention to all students, respecting the diversity, commitment and dedication to the profession, coollaboration, sharing and a strong team work, the eagerness of learning, excellence, and innovation.

\section{METHOD}

\section{Research Design}

This research is a qualitative research with phenomenology type. The research was conducted in six schools in Bangka Belitung Province. The schools in the Island of Bangka are; SMP N 1 Payung, SMP N 3 Payung, and SMP Muhammadiyah Pangkal Pinang. The schools located in the Island of Belitung are; SMP N 3 Tanjung Pandan, SMP Muhammadiyah Tanjung Pandan, and SMP N 3 Kelapa Kampit.

\section{Participants}

The subjects of this research were selected using purposive and snowball sampling techniques as presented by Lincoln \& Guba (1985), in which containing the following principles; 1) emergent sampling design, 2) serial sample of sample units, 3) continuous adjustment of focusing of the sample, 4) selection to the point of redundancy. The first step was the researcher determines the key informants in each school of the research location. Based on purposive sampling technique, it was determined as key-informants are principal and vice principal. Second step, through snowball sampling technique, the researcher asked the key informants, who were the principal and vice principal, on whom among the teachers and students have a deep understanding about the research topic. Based on these techniques, the researchers obtained participant data as described in table 1. 
Table 1

Research Participants

\begin{tabular}{lll}
\hline Schools & Informants & Sex \\
\hline SMP N 1 Payung & $\begin{array}{l}\text { Vice Principal of Curriculum, } \\
\text { 10 Teachers, 10 Students }\end{array}$ & $11 \mathrm{M}, 10 \mathrm{~F}$ \\
\hline SMP N 3 Payung & $\begin{array}{l}\text { Principal, Vice Principal of Curriculum, } \\
\text { 10 Teachers, 10 Students }\end{array}$ & $12 \mathrm{M}, 10 \mathrm{~F}$ \\
\hline $\begin{array}{l}\text { SMP Muhammadiyah } \\
\text { Pangkal Pinang }\end{array}$ & $\begin{array}{l}\text { Principal, Vice Principal of Curriculum, } \\
\text { 10 Teachers, 10 Students }\end{array}$ & $12 \mathrm{M}, 10 \mathrm{~F}$ \\
\hline $\begin{array}{l}\text { SMP N 3 Tanjung } \\
\text { Pandan }\end{array}$ & $\begin{array}{l}\text { Vice Principal of Curriculum, } \\
\text { 10 Teachers, 10 Students }\end{array}$ & $10 \mathrm{M}, 11 \mathrm{~F}$ \\
\hline $\begin{array}{l}\text { SMP Muhammadiyah } \\
\text { Tanjung Pandan }\end{array}$ & $\begin{array}{l}\text { Principal, Vice Principal of Curriculum, } \\
\text { 10 Teachers, 10 Students }\end{array}$ & $10 \mathrm{M}, 12 \mathrm{~F}$ \\
\hline $\begin{array}{l}\text { SMP N 3 Kelapa } \\
\text { Kampit }\end{array}$ & $\begin{array}{l}\text { Principal, Vice Principal of Curriculum } \\
\text { 10 Teachers , 10 Students }\end{array}$ & $11 \mathrm{M}, 11 \mathrm{~F}$ \\
\hline
\end{tabular}

\section{Data Collection and Analysis}

The technique of data collecting in this research was done through; in-depth interviews, participant observation, and documents analysis. In extracting the data, the researcher played a role as the human instrument, meanwhile for the sake of research's fluency and direction, the researcher was guided by research instruments in the form of; interview guideline, observation guideline, and documents analysis guideline. Data analysis technique used in this research was interactive inductive model of Miles and Huberman (1994), covering three stages; data reduction, data display, and conclusions and verification. The data reduction was done by summarizing, selecting the essentials, removing irrelevant data, focusing on what matters, then searching for the theme and pattern. The data display was performed by displaying all relevant data into research reports in the form of brief descriptions, relationships between categories, and narrative text description. Conclusions and verification were made by comparing, collecting, and synchronizing strong evidence in answering research questions that have been proposed.

\section{FINDINGS}

The findings of this research are discussed according to sub-topics based on the themes that emerged through interviews and observations to the respondents. The main theme of values education at SMP in Bangka Belitung Province is formulating the school's vision based on the values for which it is achieved through values education strategy which contains; values habituation, values role model, values internalization, values integration in learning, and culturing values.

\section{Formulation of School Vision Based on Values}

School vision has an important role in directing into situations and conditions in which the school wants to be brought. Based on the interview of principal and teachers, supported by the results of observation and documentation, it was found a vision formulation of those six observed schools. From the formulation of the vision of those 
six schools, some values were identified as the references for the school in developing the values education.

After having the data reduction from the observed schools, there are four concepts that often appear in the formulation of school vision, they are; iman-taqwa (faith-piety), good akhlaq (moral), science-technology, and having environmental insight, that can be seen in table 2. These four values are the blueprints of stake holders in formulating policies, programs, curriculum, and various activities at school.

Table 2

Intensity of Values in School Vision

\begin{tabular}{llllllll}
\hline Values that Appear in School Vision & 1 & 2 & 3 & 4 & 5 & 6 & Intensity \\
\hline The nation's culture & v & - & - & - & - & v & 2 \\
\hline Having environmental insight & v & - & - & v & v & - & 3 \\
\hline iman-taqwa (faith-piety) & v & v & - & v & v & - & 4 \\
\hline Science and Technology & v & - & v & v & - & - & 3 \\
\hline Good akhlaq (moral) & - & v & v & - & - & v & 3 \\
\hline Qualified & - & v & - & - & - & - & 1 \\
\hline Superior & - & v & - & - & - & - & 1 \\
\hline
\end{tabular}

Information: 1. SMP N 1 Payung, 2. SMP N 3 Payung,, 3. SMP Muhammadiyah Pangkal Pinang, 4. SMP N 3 Tanjung Pandan, 5. SMP Muhammadiyah Tanjung Pandan, 6. SMP N 1 Kelapa Kampit

Iman-taqwa (faith-piety) is the most appearing value. From the six schools, four schools have vision formulas containing the value of Iman-taqwa (faith-piety). The core value of the vision formulation indicates the quality of the graduates that the school will produce, which have the character of full quality of human beings that have superiority based on faith and piety.

\section{Formulation of Values Education Strategy}

Strategy in the concept of values education in this section refers to the definition of strategy in a very broad sense, ie all plans, methods, programs, and school activities in order to implement values education at SMP in Bangka Belitung Province. From the six observed schools, there were five strategies of values education found namely; values habituation, values role model, values integration to the subjects, values internalization, and culturing values.

Table 3

Values Education Strategy

Values Education Strategy

Values Habituation

Values Role Model

r

\begin{tabular}{lllllllll}
\hline Values Integration In Learning & $\mathrm{V}$ & - & - & $\mathrm{v}$ & $\mathrm{V}$ & - & 3 \\
\hline
\end{tabular}

\begin{tabular}{llllllll}
\hline Values Internalization & $\mathrm{V}$ & - & - & - & - & $\mathrm{V}$ & 2
\end{tabular}

\begin{tabular}{llllllll}
\hline Culturing Values & - & - & - & V & V & - & 2
\end{tabular}

Information: 1. SMP N 1 Payung, 2. SMP N 3 Payung,, 3. SMP Muhammadiyah Pangkal Pinang, 4. SMP N 3 Tanjung Pandan, 5. SMP Muhammadiyah Tanjung Pandan, 6. SMP N 1 Kelapa Kampit 
Table 3 shows that values habituation, values role model, and values integration in learning are the most dominant in the values education strategies in schools. The internalization of values and culturing values are also practiced in some schools although the frequency is not as frequent as the previous three strategies.

\section{Values Habituation}

Habituation is an educational process that takes place by familiarizing students to behave, speak, think and perform certain activities according to good habits. Habituation is an important stage for the students to start socializing, social interaction in the school environment. Habituation of good values in school requires the role of various parties, especially teachers. A teacher at SMP N 1 Payung revealed that:

"The role of the teacher as a substitute for parents in school is needed in order to develop the desired behavioral habits (eg discipline, orderliness, respect for others and loving fellow God's creatures) through examples and concrete actions". ${ }^{1}$

In more detail, the task of the teacher is to educate the students by providing direction and motivation to achieve the goals both short and long term, providing facilities to achieve the goals through adequate learning experiences, and assisting the development of personal aspects such as attitudes, values and adaptation. Based on the interviews, the guidance and counseling teacher at SMP N 1 Payung stated that:

"The children's habits are influenced by the figures who become the role model in their behavior. Student is accustomed to be disciplined, orderly, courteous, because the parents and teachers who become the figures always invite and give example to the child."

Various habituations have been done by the school as the attempt to embed the values to the students. A teacher at SMP N 1 Payung revealed that: "Students here are accustomed to take care of the natural and social environment. Inviting the students to care about flood victims in Belitung, formerly in West Bangka, so that the students will care about each other in order to raise the students' empathy." Another teacher at SMP N 1 Payung stated: "An awareness of the importance of the natural environment sustainability is Clean Saturday which is done once a week, so there will be an awareness to throw garbage in its place. The impact that can be seen now is that the awareness of the students are already arised. Recycling is utilized for workshop and some even has been selling points." Another teacher at SMP N 1 Payung revealed:

"In the school, it is encouraged to campaign about disposing the garbage according to its type, which is organic and non-organic garbage. In the subjects of art workshop, the used materials in our school are sorted out even some used materials can be sold. There is a bazaar in Payung market that is often followed by the students; they sell flowers, bags, and dishes from their work. Students feel

\footnotetext{
${ }^{1}$ The interviews in this research were conducted in Indonesian Language. In consideration of writing this paper, they were translated into English without reducing the meaning or substances of the respondents' answers in the school
} 
happy because the dirty scrap can apparently be processed to be beautiful. In the class, they are also introduced to the types of garbage. There are special teams given the tasks per week, and in schools, there are also garbage banks."

Various habits conducted in schools are part of the school's efforts to realize the achievement of the school vision based on values. The values of Iman-taqwa (faithpiety) and good akhlaq (moral) which are listed in the vision of the school will color the various habits in school. It is proven that all schools habitualize religious activities such as reading Koran every morning, praying in congregation at school, Dhuha prayer and so on, which all of them are forms of the value of Iman-taqwa (faith-piety) and good akhlaq (moral). Through interviews, Principal of SMP N 3 Payung revealed:

"Many religious activities are held in this school. Daily activities of children in school are always controlled, in Romadhon month children are given activity logs during Romadhon month, Dhuha prayer is also routinely done every first break time, and there is also activity of yasinan (reading surah Yaasin from the Koran) held every week. A number of religious activities here are designed because it fits to the school vision based on Iman-taqwa (faith-piety)."

The results of the interviews show that although public schools, many habits of religious activities (Islam) are held in schools, such as praying Dhuha, Dhuhur prayers in congregation, fasting and various kinds of worship in the month of Romadhon, even yasinan (reading surah Yaasin from the Koran) activitiy. This data is reinforced by the interviews of Islamic Education teacher at SMP N 3 Payung, who at the same time is the coach of Rohani Islam (students organization focus on deepening and strengthening the teachings of Islam) at school. "Rohani Islam routine activities are held on Friday afternoon, children are enthusiastic. In these activities, it is intended to cultivate Islamic personality, pray five times consistently, memorize 30 chapters of the Koran, and join a contest of memorizing surah Yaasin. From these activities, it was found out that some children successfully memorized surah Yaasin".

Compared to public shcools, SMP Muhammadiyah Tanjung Pandan even makes the programs and activities of Islam become the basis and superior programs offered to the community. Principal of the school stated:

"As a part of character education, the school has a special program, Iman and taqwa (faith and piety) activities in the morning including strengthening the praying, tadarus (reciting) the Koran which is carried out regularly on Wednesday and Friday. The activity runs for 20 minutes before the teaching and learning activities begin. Here are the examples of Iman and taqwa (faith and piety) activities done in our school: the prayer of Dhuha which is done every day, praying dhuhur congregation, Friday prayers for male students, meanwhile women have keputrian (related to women) activities. So, when the male students have Friday prayer, female students have special activities in the form of keputrian (related to women) activities for which the material delivered in the activities is directly related to the women's needs such as about female reproduction fiqh." 
For the Muhammadiyah Schools, religious activity is a necessity. In the consideration that not only having the function of education, but Muhammadiyah schools also function as da'wah and cadre institutions which means that Muhammadiyah schools convey the ideology of Muhammadiyah to the students in their educational activities. In fact, the students in the Muhammadiyah Schools are a cadre of the affiliation (Muhammadiyah) that is required to comprehend and practice the ideology of Muhammadiyah movement. A teacher of Civil Education at SMP Muhammadiyah Tanjung Pandan said: "The most highlighted points here are Islamic values, Islamic dress, language structure, manners in language, eating and drinking according to Islamic teachings". The same thing was conveyed by the Arabic teacher; "Here is very emphasizing on the formation of Imantaqwa (faith-piety), the values of kemuhammadiyahan (related to Muhammadiyah), praying procedure fitting tarjih (Legal Affairs Committee) of Muhammadiyah".

Religious activities (Islam) are also developed in SMP N 3 Tanjung Pandan. Even, in addition to carry out various kinds of religious activities with high enough intensity, this school launched the program of $100 \%$ eradication of Koran illiteracy. It is because the school has a target which requires all Muslim students should be able to read the Koran. Islamic Education teacher of SMP N 3 Tanjung Pandan said: "The school has a goal to carry out religious values through various religious activities. In fact, this school also proclaims to $100 \%$ complete eradication of Koran illiteracy."

\section{Role Model of Values}

The role model of values which come from the principals, teachers, parents, and educational personnel are the important factors in the formation of student's values. The incompatibility of both words and actions from the teachers will make the students difficult to receive advice and lessons about values in school.

Knowing the importance of role model in values education, both principals and teachers of SMP at Bangka Belitung attempt to direct all educators and educational personnels at school to be the values role model to the students. Deputy Principal of Curriculum at SMP N 1 Payung explained:

"Any regulations applied in schools are not just for the students but also for the teachers; for instance when there is a regulation of "no smoking" in school, the rule prevails to all parties in the school, including principal and teachers. In addition, teacher must be a role model in dressing."

The same thing is expressed by the principal of SMP N 3 Payung as follows: "Another example is when applying time discipline for which I come to school before the teachers and students come to school. Without applying that method, it is difficult to prevail discipline in this school."With a slight difference of editorial, the principal of SMP Muhammadiyah Tanjung Pandan said: "To teach teachers and students discipline time, I have to come in time. It is also a form of our appreciation of time".

From the interviews with the three resource people above, it can be concluded that the principals and teachers of SMP in Bangka Belitung are trying to be a role model for their students in developing values in school. The same thing also happens in SMP N 3 Kelapa Kampit. The principal stated: "Do not let unfair rule. If you expect students to 
arrive before $7 \mathrm{pm}$, the teacher must come before $7 \mathrm{pm}$ as well. That way, Alhamdulillah students feel reluctant to come late. Even here students often welcome teachers in front of the school".

\section{Values Internalization}

Values internalization is a process or means of cultivating normative values that determine the desired behavior of a system for which it educates people based on the values applied in a society. The values internalization at SMP in Bangka Belitung is done in various ways, for example; by singing national anthems during the ceremony in order to instill nationalism values, reciting the prayer at the beginning and end of the lesson in order to internalize religious values, creating a reading literacy program in order to internalize the values of curiosity and reading habit. This is supported by the interviews of teachers in schools. Deputy Principal of curriculum in SMP N 1 Payung stated that:

"Before being appointed as the school which organizes a program of Strengthening the Character Education, this school is already character-based. Characters are internalized in various ways. Usually at the beginning of the lesson, students are guided by a teacher to sing the national anthem and at the end of the classroom activities, they are singing regional song".

Singing both national and local songs is one of the ways to internalize values of nationalism to students. While in SMP N 3 Kelapa Kampit, the value of nationalism is internalized through flag ceremony every Monday. Besides strengtehning the value of nationalism, religious value is also internalized in a manner which is similar to the internalization of the nationalism value. The value of the religion is internalized through; praying before and after lessons, having Rohani Islam activity, and conducting religious events on the commemoration of the holy-day of religion (Islam). Meanwhile, the value of reading habit is internalized through the literacy movement program (Interview with guidance and counseling teacher of SMP N 3 Tanjung Pandan).

\section{Values Integration in Learning}

Values integration in learning is the process of integrating certain values into different concept so that it becomes a coherent and inseparable unity. The results show that teachers in the classroom have tried to integrate values in every learning they do in different ways. A Biology Teacher at SMP N 1 Payung revealed that:

"There are many themes in the biology lessons that I use to instill the value of faith in God. Let's say when I explain the theme of reproduction then reproduction is returned to thank to God. We as humans have been endowed by God's various limbs including reproductive tools so that humans can continue their offspring."

Moreover, the values integration is also done in Indonesian language learning. Indonesian Language teacher at SMP N 3 Kelapa Kampit stated that:

"The integration of values education in Indonesian Language learning is done by integrating one of the topics to the education values through drama or role play. 
There are students who act as policemen, some also act as criminals. The drama is held in order to explain to the students that the person whose good behavior will be rewarded, and vice versa. "

From the various examples of values integration conducted by the teachers, there is a clear pattern of how teachers integrate values education in learning. The integration is done in every learning process, no matter what the material and methodology is, it should contribute to the formation of the students character. The emphasis of which character to teach depends on the purpose of each learning in the classroom.

\section{Culturing Values}

Culturing Values is an important tool for developing the students' value. Basically, there are three layers of culture; artifacts, values and beliefs, and assumptions that lie on the base layer. The three layers of culture are interconnected with each other in shaping the students'value at school. The value formation through artefact culture in the school is showed through these following writings: Buanglah Sampah Pada Tempatnya (throw the garbage in the waste bin), Kawasan Bebas Asap Rokok (No-Smoking Area), Gunakan Air Secukupnya (use water wisely) (Obeservation at SMP N 1 Payung). These slogans appear on the boards of the front school, class walls, around canteens, and strategic places so that students can see them easily.

In other schools, the slogans: Hemat Listrik (save electricity), Sekolah Aman (safe school), dan Bebas Narkoba (Drugs Free) (Observation at SMP N 3 Tanjung Pandan) are also put on the several strategic places so that the students can easily see them. Meanwhile in SMP Muhammadiyah Pangkal Pinang, the artifacts are written about the Cleanliness which becomes the Part of Faith, and also pictures of Ahmad Dahlan and Nyai Ahmad Dahlan which are displayed in the principal's office. Artifact is one of the channels in culture that can be a tool in culturing values to students.

In terms of beliefs, there are several emerging concepts that illustrate how teachers' belief toward the students can affect on the culturing values. According to the interviews with the principal, vice principal, and teachers, it can be inferred about the teachers' belief toward the students. After the data reduction conducted, there were seven concepts found inside that illustrate the teachers' belief. The concepts found are presented on the table 4 below.

Table 4 shows that the belief "Children are unique" is the dominant view of the teachers toward the students. From the six observed schools, the concept appeared four times. It is similar to the belief " the children are a trust from God" which showed up four times. Meanwhile the other beliefs, namely; "children as assets", "students as friends", "students are considered as their own children", "children as psychological beings", and "children as religious beings" appeared once from the six observed schools. 
Table 4

Teachers' belief towards their students

\begin{tabular}{llllllll}
\hline Teachers' belief towards the students & 1 & 2 & 3 & 4 & 5 & 6 & Intensity \\
\hline Childern are uniq & v & - & v & - & v & v & 4 \\
\hline Children as asset & v & - & - & - & - & - & 1 \\
\hline Students as friends & v & - & - & - & - & - & 1 \\
\hline Students as psychological being & - & v & - & - & - & - & 1 \\
\hline Children are a trust from God & - & v & v & v & - & v & 4 \\
$\begin{array}{l}\text { Students are considered as their own } \\
\text { children }\end{array}$ & - & - & - & v & - & - & 1 \\
Children as religious being & - & - & - & & v & - & 1
\end{tabular}

Information: 1. SMP N 1 Payung, 2. SMP N 3 Payung,, 3. SMP Muhammadiyah Pangkal Pinang, 4. SMP N 3 Tanjung Pandan, 5. SMP Muhammadiyah Tanjung Pandan, 6. SMP N 1 Kelapa Kampit

The teachers' belief toward students is a part of culture that determines how the teachers ultimately treat students. The belief "the children are unique" is a view based on a psychological perspective which states that every child born into this world has different characters from one another. No one is exactly the same. All have special characters that are not owned by others. This view requires teachers to treat students individually, in accordance to the characters they have. This perspective makes the students feel comfortable with themselves because their existence, whatever it is that is received by others, especially teachers.

\section{DISCUSSION AND CONCLUSION}

The implementation of values education at SMP in Bangka Belitung begins with the formulation of school vision based on the values. This values-based school vision is the foundation for all school members, such as principals, teachers, students, and educational personnel to conduct learning activities at school. The formulation of values-based school vision is an important factor for the implementation of values education, because the success of school programs is preceded by the formulation of vision as a guide to all policies, programs and activities that exist in schools (Raihani, 2008).

The values-based school vision is achieved through the formulation of values education strategies that include; values habituation, values role model, values internalization, values integration in learning, and culturing values. There were two concepts found in this reseach; values habituation and values role model which are in line with the concepts found by Mislia \& Darman (2016). Meanwhile the other three concepts as mentioned by Maragustam (2014) which are values habituation, values role model, and culturing values also strengthen the results of this research.

The formation of values through habituation is the most dominant and prevalent way in schools. It also fits perfectly to the character of junior high school students who are entering adolescence, in which the character formation phase is acquired through habituation. William Kilpatrick as quoted from Madjid and Andayani (2012) stated that one of the causes of a person's inability to do good deeds even though the person already 
has knowledge of the good (moral knowing) is because the person is not trained to do good deeds. This statement means that somebody goodness needs to be habitualized, so that good values can be something that is commonly do every time, because it is trained and accustomed. Students who are accustomed to practice the value of goodness, thus they will be accustomed to do good values even though they are at outside of the school where the process of habituation has been done. In this regard, Sutrop et al. (2013) explained that by values education, students are not only aware of the values but also living with values. In the next stage, the values habituation that students do continuously will form the value culture in school.

In addition to the values habituation, values role model also become important strategy for principals and teachers to cultivate values to the students. The above findings are in accordance with the results of previous researches. The research's results of Ulavere \& Veisson (2015); Amani (2013) have proven this fact before, that the role of teachers as role models is important in values education. Moreover, internalization also becomes a vital process in cultivating values to the students. This is in accordance with Muslich (2011), who stated that values education should not only touch on the level of the introduction of norm or values, but also must be at the level of internalization and tangible action in everyday life. The success of the school in implementing the values to the students can be seen from how the students internalize the value well that can be seen through the actions or behavior of students' daily life (Koesoema, 2010).

Educators at SMP Bangka Belitung also integrate values education in every lesson. Therefore, the cultivation of values to the students is not only the responsibility of particular teacher, but all teachers in the schools. This is in line with the findings that character education should be integrated with all subjects for better results (Novianti, 2017; Krull, 2000). The same result was also expressed by Sutiyono (2013) who said that the design of values education should not be in the form of certain subject, but the practice of those values is absorbed through every learning activity in school. The findings of this research denied the results of Hadi's research (2015) which revealed that teachers in schools do not yet have enough skills to integrate values in classroom learning. Hadi's research (2015) is not applied to the educators in this research's context.

Meanwhile the belief "children are trust from God" is a belief built upon an understanding of the religion that the children are a trust from God who need to be guarded, cared for, educated, and developed the potential. Applying the belief "children are a trust from God" makes the teachers aware that teaching students at school is more than just running a profession to earn livelihoods, but also a form of devotion to God (worship). This idea is supported by the research of Chong \& Cheah (2009) who asserted that the main values possessed by a teacher will support the success of the curriculum implementation at school.

The results also show that values derived from the religious teachings, namely the value iman-taqwa (faith-piety) and good akhlaq (morals) are still the most regarded values in the schools' community. This reasearch also verifies the previous research findings showing that there is a growing religiosity of students in schools now, even in public schools which are not religious schools (Rahima, 2008). The phrase "with the basis of 
iman-taqwa (faith-piety)..."shows that religious beliefs and values are the foundation for the school community to step into the school processes and procedures. It also means that these values and beliefs serve as a guide for schools to adapt and adopt the changes that occurr as a result of an era development. This fact also supports the theory of Cassanova (2003) which stated that religious values again have a vital role in modern human life, especially for Eastern citizen. This fact actually contradicts the thought of most great Western writers who generalize that religious values will be abandoned from the life of modern human.

The emergence of the iman-taqwa (faith-piety) and good akhlaq (morals) values at once also reflects that the values developed in the learning process at SMP Bangka Belitung is indeed relevant to the national education system in Indonesia, for which one of the main aims of national education is forming godly, pious, and well-akhlaq humans. In addition, the learning outcome of K-2013 is about achieving the core competency 1 (religious character/ faith-piety) and core competency 2 (social attitude/good akhlaq).

\section{ACKNOWLEDGEMENT}

On this occasion, the researcher would like to thank The Ministry of Research Technology and Higher Education, Indonesia, that has been willing to grant the overall cost of this research. Thanks also to Ahmad Dahlan University that has provided research facilities and infrastructure. We also thank to the resource persons who have helped in the process of extracting the research data.

\section{REFERENCES}

Amani, J. (2013). Moral Values Education in Terms of Graduate University Students' Perspectives: A Jordanian Sample. International Education Studies, 6(2), 142.

Arifin, Bafadal, I., Imron, A., \& Sonhadji A. (2017). Cultivating Character Education Through Transforming School Cultural Values. Studia Humanitatis, 37 (4), http://sthum.ru/content/arifin-bafadal-i-imron-sonhadji-cultivating-character-education-throughtransforming-school

Bette, E. (2011). Re-Engineering Values Education in Nigerian Schools as Catalyst for National Development. International Education Studies, 4(1), 152.

Brady, L. (2011). Teacher Values and Relationship: Factors in Values Education. Australian Journal of Teacher Education, 36(2), 57-66. http://dx.doi.org/ $10.14221 /$ ajte. $2011 \mathrm{v} 36 \mathrm{n} 2.5$

Cassanova, J. (2003). Public Religion in The Modern World. Terj. Nafis Irkhami, Surabaya: Pustaka Eureka.

Cavus, S. (2015). Determination of tendencies of secondary school students to tolerance and variables affecting their tendencies to tolerance. Anthropologist, 20 (3), 599-615.

Chong, S. \& Cheah, H. M. (2009). A Values, Skills and Knowledge Framework for Initial Teacher Preparation Programmes. Australian Journal of Teacher Education, 34(3), 1-17. http://dx.doi.org/10.14221/ajte.2009v34n3.1 
Hadi, R. (2015). The Integration of Character Values in the Teaching of Economics: A Case of Selected High Schools in Banjarmasin, International Education Studies, 8 (7), 11-20. http://www.ccsenet.org/journal/index.php/ies/article/view/49836

Holmes, K. \& Crossley, M. (2004). Whose Knowledge, Whose Values? The Contribution of Local Knowledge to Education Policy Processes: A Case Study of Research Development Initiatives in the Small State of Saint Lucia. Compare.

Kemendiknas. (2010). Kurikulum Pendidikan Nasional. Badan Penelitian dan Pengembangan Kurikulum.

Kirschenbaum, H. (1995). One Hundred Ways to Enhance Values and Morality in Schools and Youth Settings. Boston: Allyn and Bacon.

Koesoema, D. (2010). Pendidikan Karakter Strategi Mendidik Anak Di Zaman Global. Jakarta: Gramedia.

Krull, E. (2000). Pedagoogilise psyhholoogia kasiraamat (Handbook of educational psychology). Tartu: likooli kirjastus.

Lickona, T. (2004). Character Matter. New York: Touchstone Rockefeller Center.

Lincoln, Y. S. \& Guba, E. G. (1985). Naturalistic Inquiry. Newbury Park. CA: Sage Publications.

Lovat, T.\& Toomey, R. (eds). (2009). Values Education and Quality Teaching. Springer Science+Business Media.

Lovat, T. \& Clement, N. (2008). Quality teaching and values education: coalescing for effective learning. Journal of Moral Education, 37 (1) 1-16. DOI: 10.1080/03057240701803643. http://dx.doi.org/10.1080/03057240701803643:

Majid, A. \& Andayani, D. (2012). Pendidikan karakter Perspektif Islam. Bandung: Remaja Rosdakarya.

Maragustam. (2014). Filsafat Pendidikan Islam: Menuju Pembentukan Karakter Menghadapi Arus Global. Yogyakarta: Kurnia Kalam Semesta.

Miles, M. B. \& Huberman, A. M. (1994). Qualitative data analysis: An expanded sourcebook. Thousand Oaks: Sage Publications.

Mislia, M. A. \& Darman, M., D. (2016). The Implementation of Character Education through Scout Activities. International Education Studies, 9 (6), 130.

Muqowim. (2014). Softskills-Based Learning Process dan Masyarakat Ekonomi Asean (MEA). Seminar Nasional PGSD dan BK UAD. 14 Desember.

Muslich, M. (2011). Pendidikan Nilai Menjawab Tantangan Krisis Multidimensional. Jakarta: Sinar Grafika Offset.

Nesbitt; Arweck, E., E. \& Jackson, R. (2005). Common Values for the Common in School? Using two Values Education Programmes To Promote Spiritual And Moral 
Development. Journal of Moral Education, $34 \quad$ (3), 325-343. https://www.tandfonline.com/doi/abs/10.1080/03057240500206154?mobileUi=0\&journ alCode $=\operatorname{cjme} 20$

Nguyen, Q. (2016). The Vietnamese Values System: A Blend of Oriental, Western and Socialist Values. International Education Studies, 9 (12), 32.

Novianti, N. (2017). Teaching Character Education to College Students Using Bildungsromans. International Journal of Instruction, 10 (4), 255-272. https://doi.org/10.12973/iji.2017.10415a

Nurdin, E. (2015). The Policies on Civic Education in Developing National Character in Indonesia. International Education Studies, 8 (8) 2015, 207.

Peraturan Presiden Republik Indonesia No. 87 Tahun 2017 tentang Penguatan Pendidikan Karakter.

Prencipe, A. \& Helwig, C., C. (2002). The Development of Reasoning about the Teaching of Values in School And Family Contexts. Child Development.

Print, M. (2000). Curriculum Policy, Values and Changes in Civics Education Australia. Asia Pacific Journal of Education, 20 (1), 21-35.

Rahima. (2008). LaKIP Jakarta dan Maarif Institute dalam Farha Ciciek. Merawat Tradisi Moderat Kaum Muda. PPIM UIN Jakarta.

Raihani. (2008). An Indonesian Model of Successful School Leadership. Journal of Educational Administration, 46 (4), 481-493.

Sankar, Y. (2004). Education in crisis: A value-based model of education provides some $\begin{array}{llll}\text { guidance. } & \text { Interchange, } & 35 & (7),\end{array}$ https://link.springer.com/article/10.1023/B:INCH.0000039023.98390.88

Savucu, Y.; Kanat, M.; Karadağ, M.; Süreyya. Y.; Sezer \& Ali S. Yücel. (2017). International Education Studies, 10 (7), 40.

Senturk, L. \& Aktas, E. (2015). Comparison of Turkish language textbooks for natives in Turkey and in Romania according to value education. Journal of Values Education, 13. 215-243.

Sutiyono. (2013). Penerapan Pendidikan Budi Pekerti Sebagai Pembentukan Nilai Siswa Di Sekolah: Sebuah Fenomena Dan Realitas. Jurnal Pendidikan Karakter, 3(3), 2.

Sutrop, M.; Harro-Loit, H. \& Jung, N. (2013). Kooli vaartusarenduse hindamismudelmiks ja kuidas? [Values education assessment model for schools: Why and how?] In M. Sutrop, (Ed.), Vaartuspıhine kool. Eesti ja maailma kogemus [Valuesbased school: Experience from Estonia and the world] Tartu: University of Tartu Centre of Ethics. (pp. 199-215). 
Taplin, M. (2002). Can we, should we, and do we integrate values education into adult distance education? Opinions of stakeholders at the open university of Hong Kong. International Journal of Lifelong Education, 21 (2), 142-161. https://www.tandfonline.com/doi/abs/10.1080/02601370110111709

Tatto, M. T.; Arellano, L. A.; Tapia, M.; Varela, A. L. \& Rodriguez, M. (2001). Examining Mexico"s Values Education in a Globally Dynamic Context. Journal of Moral Education, $30 \quad 30$ (2), 173-198. https://www.tandfonline.com/doi/abs/10.1080/03057240120061405

Tutkun, E.; Görgüt, I. \& Erdemir, I. (2017). Physical Education Teachers' Views about Character Education. International Education Studies, 10 (11), 86.

Ulavere, P. \& Veisson, M. (2015). Values and Values Education in Estonian Preschool Child Care Institutions. Journal of Teacher Education for Sustainability, 17 (2), 108124. https://content.sciendo.com/view/journals/jtes/17/2/article-p108.xml

Undang-Undang Sistem Pendidikan Nasional Republik Indonesia Nomer 20 Tahun 2003.

Yildirim, B. I. \& Dilmac, B. (2015). Investigation of cyber victimization in terms of humanitarian values and socio-demographic variables. Journal of Values Education, 13 (1), 7-40. 